\title{
ПРАКТИЧЕСКАЯ
}

\section{ЭФФЕКТИВНОСТЬ ФИТОТЕРАПИИ}

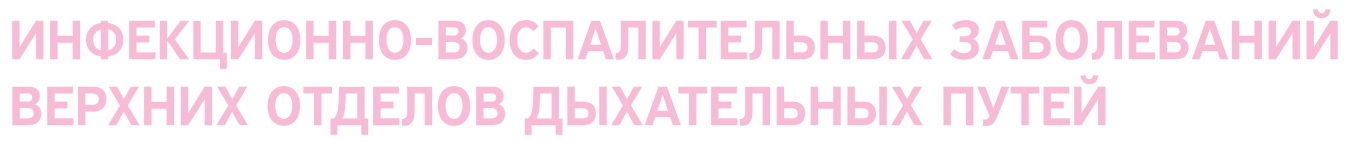

В статье представлены данные о практической эффективности препарата умкалор на основе экстракта пеларгонии сидовидной, в частности его антибактериальная активность. Приводятся данные мировой литературы, посвященные опыту применения экстракта пеларгонии в лечении острых воспалительных заболеваний верхних дыхательных путей, а также разбор клинического случая.

Ключевые слова: острые воспалительные заболевания верхних дыхательных путей, пеларгония, умкалор.

\section{S.V. MOROZOVA, MD, Prof., L.A. TOPORKOVA}

I.M. Sechenov First Moscow State Medical University

THE PRACTICAL EFFECTIVENESS OF HERBAL THERAPY OF INFECTIOUS-INFLAMMATORY DISEASES OF THE UPPER RESPIRATORY TRACT This article presents a practical effectiveness of the drug Umckalor (Pelargonium sidoides), its antibacterial activity. Provides data of world literature on the experience of the use of pelargonium extract in the treatment of acute inflammatory diseases of the upper respiratory tract, and case report.

Keywords: acute inflammation diseases of upper respiratorium tract, pelargonium, umkalor.

стрые воспалительные заболевания лоРорганов на сегодняшний день имеют значительный удельный вес в структуре общей заболеваемости, при этом показатель распространенности в мировой популяции составляет 6-8 человек на 1000 населения в осенне-зимний период и 2-3 на 1000 населения в летний период [1].

Острый тонзиллофарингит является одним из самых часто встречающихся заболеваний верхних отделов дыхательных путей у взрослых и детей. Превалирующим этиологическим фактором являются респираторные вирусы, реже - энтеровирусы (Коксаки В), вирус Эпштейна - Барр $[1,2]$. Среди бактериальных возбудителей первостепенным считается бета-гемолитический стрептококк группы А (БГСА, Streptococcus pyogenes), стрептококки групп С и G, Streptococcus pneumoniae, Arcanabacterium haemolyticum, анаэробы, Mycoplasma pneumonia и Chlamydia pneumonia [3-5]. Еще более редкие бактериальные возбудители острых тонзиллитов - спирохеты (ангина Симановского Плаута - Венсана).

Острый средний отит также является крайне важной проблемой и занимает до 20\% в структуре оториноларингологической заболеваемости. По статистическим данным, практически каждый второй ребенок на первом году жизни имел хотя бы один эпизод острого среднего отита, 71\% детей до трех лет перенесли острый средний отит [6]. Основными микроорганизмами, вызывающими острый средний отит, являются: Haemophilus influenzae, Moraxella catarrhalis, Streptococcus pneumoniae. До 10\% острых средних отитов имеют вирусную этиологию.

Острые риносинуситы составляют примерно 50\% в структуре оториноларингологической заболеваемости.
Часто риносинуситы протекают как осложнения ОРВИ, сопровождаются временной утратой трудоспособности и необходимостью стационарного лечения. Примерно треть пациентов ЛОР-стационара - это пациенты с острым риносинуситом [7].

Согласно EPOS-2012, принято выделять вирусный, поствирусный и бактериальный риносинусит. Чаще всего в качестве бактериальных агентов выступают Streptococcus pneumoniae, Haemophilus influenzae, Streptococcus pyogenes, Moraxella catarrhalis, Staphylococcus aureus, Pseudomonas aeruginosa, Proteus spp, Esherichia coli и ряд других патогенных и условно-патогенных штаммов бактерий. Причиной острых вирусных риносинуситов часто являются вирус гриппа А, вирус гриппа H1N1, вирус парагриппа, респираторный синцитиальный вирус (РСВ), риновирус, вирус Коксаки, аденовирус и другие [8]. До 98\% всех острых риносинуситов вызвано вирусами. Вирусный риносинусит чаще протекает в катаральной форме и характеризуется слизистыми выделениями из носа, для бактериального синусита типично слизисто-гнойное отделяемое.

Крайне актуальна проблема терапии острых риносинуситов. При бактериальных риносинуситах, в соответствии с критериями тяжести течения заболевания, широко используется антибиотикотерапия препаратами широкого спектра действия, однако при этом все чаще встает вопрос о резистентности микроорганизмов. По рекомендациям EPOS-2012, если форма риносинусита легкая, она не требует назначения системных антибиотиков. Выбор антибактериального препарата облегчает введение понятий первой, второй и третьей линии терапии. Кроме того, самого пристального внимания заслуживает возможность аллергической реакции пациента 
на препарат, в том числе формирование перекрестной аллергии, а также выраженность побочных эффектов от антибиотиков, особенно со стороны желудочно-кишечного тракта (антибиотикоассоциированная диарея) [9].

Все вышеперечисленное диктует необходимость дальнейшего поиска рациональных препаратов для эффективного безопасного лечения острых инфекционно-воспалительных заболеваний ЛОР-органов. В настоящее время существенно возросло внимание практических врачей, в т. ч. оториноларингологов, к фитотерапии, представляющей собой метод лечения различных заболеваний человека, основанный на использовании лекарственных растений и комплексных препаратов из них. Фитопрепараты - это лекарственные средства, получаемые исключительно из растительного сырья, трав, целого растения или экстракта из него и применяемые для лечения. Эти термины были предложены французским врачом Анри Леклерком (фр. Henri Leclerc, 1870-1955). Особенностью фитопрепаратов является то, что при переработке сырья (лекарственных растений) для их получения целью является сохранение всего комплекса активных веществ, а не выделение одного [10].

Фитотерапия отличается своей безопасностью, в большинстве случаев ее можно применять у детей и беременных женщин. К положительным сторонам применения фитопрепаратов можно отнести и высокий уровень комплаентности со стороны пациентов. Так, в Бийске в 2007 г. было проведено анкетирование родителей и учащихся кадетской школы. Было опрошено 200 человек: 100 учащихся и 100 родителей. 74\% родителей и 85\% детей ответило, что сочетают одновременно лечение медикаментами и травами; 20\% родителей и 12\% детей выбирают лечение лекарственными растениями, и только $6 \%$ родителей и $3 \%$ детей предпочитают медикаментозные средства [11].

Также важно подчеркнуть, что сегодня применение фитотерапии стало более удобным, т. к. отпала необходимость самостоятельного приготовления отвара, настоек и т.д. В настоящее время в аптеках представлен широкий спектр фитопрепаратов в жидких и таблетированных формах.

Современным представителем фитопрепаратов с активным антимикробным и муколитическим действием является препарат умкалор, который представляет собой раствор для приема внутрь в виде прозрачной или слегка опалесцирующей жидкости от светло-коричневого до красновато-коричневого цвета. Взрослым и детям старше 12 лет умкалор назначают по 20-30 капель 3 р/сут, детям в возрасте от 6 до 12 лет - по 10-20 капель 3 р/сут, детям от 1 года до 6 лет - по 5-10 капель 3 р/сут.

Основа препарата умкалор - жидкий экстракт из корней пеларгонии сидовидной EPs 7630 - вид южноафриканского рода пеларгониум (лат. Pelargōnium) семейства гераниевых (лат. Geraniaceae). Лечебные свойства пеларгонии сидовидной обусловлены высокой концентрацией активных действующих веществ: флавоноидов, кумаринов, органических кислот. Кумарины способны оказывать противовоспалительное и иммуномодулирующее действие, обладают хорошо выраженным антибактериальным воздействием в отношении широкого спектра грамположительных и грамотрицательных микроорганизмов, включая
Streptococcus (pneumoniae u haemolitic), Staphylococcus aureus; Klebsiella pneumoniae, Hemophilus influenzae, Pseudomonas aeruginosa, Proteus mirabillis, E. coli; Mycobacterlum tuberculosis. Флавоноиды оказывают противовирусное, противовоспалительное, противоаллергическое и антиоксидантное действие, имеют бактериостатическую активность по отношению к антибиотико-резистентным бактериям. Фенолокислоты содействуют выработке интерферона, защищающего неинфицированные клетки от вируса; танины также обладают антибактериальным действием и могут связывать бактериальные токсины. Уникальное сочетание широкого спектра растительных соединений в экстракте из корней пеларгонии сидовидной способствует усилению их фармакологических свойств, и в комплексе эти вещества могут эффективно воздействовать практически на любые острые вирусно-респираторные инфекции. Кроме того, препараты пеларгонии обладают антибактериальным действием, что способствует предупреждению развития бактериальных осложнений [12].

В 2003 г. врачами из Германии, Мексики и Украины проводилось двойное слепое плацебо-контролируемое исследование, в которое было включено 143 ребенка от 6 до 10 лет с тонзиллофарингитом, вызванным бета-гемолитическим стрептококком. Все дети имели 8 или более баллов по шкале тяжести острых тонзиллофарингитов, и давность симптомов не более 48 часов. В основной группе, в которую вошло 143 ребенка, использовали препарат пеларгонии, в группе контроля, в которую вошли 70 детей, использовали плацебо. В 95\% по результатам исследования было выявлено статистически значимое различие результатов лечения в пользу основной группы, в которой улучшение наступало быстрее. Дополнительной рекомендацией авторов было назначение экстракта пеларгонии в течение первых двух суток от начала развития тонзиллофарингита [13].

Оториноларингологами из Швейцарии, Бельгии и Германии в 2009 г. было проведено двойное слепое многоцентровое плацебо-контролируемое исследование, в котором приняло участие 103 пациента с острым риносинуситом бактериальной природы. У всех пациентов диагноз был подтвержден рентгенологически, а также проводилась оценка степени тяжести острого риносинусита по специализированной шкале. В исследование были включены пациенты с острым риносинуситом, соответствовавшим 12 и более баллам по 24-балльной шкале. Основной группе пациентов был назначен экстракт пеларгонии в количестве 60 капель 3 раза в день, контрольная группа пациентов получала плацебо. Максимальный срок лечения составлял 22 дня с промежуточной оценкой результатов на 7-й день терапии. При промежуточной оценке в группе, получавшей в качестве основной терапии экстракт пеларгонии, наблюдалось снижение количества баллов по шкале тяжести течения синуситов на 5,5 против 2,5 в группе плацебо. Таким образом, разница между двумя группами составила 3 балла. Данный результат полностью коррелировал с данными осмотра, рентгенологической картины и другими клинико-лабораторными показателями. Таким образом, был сделан вывод об антибактериальных свойствах 
пеларгонии в качестве базисного препарата при лечении острого риносинусита [14].

В 2010 г. в Турции прицельно изучали антибактериальную активность пеларгонии. Для этого брались мазки со слизистой оболочки глотки пациентов с острыми тонзиллофарингитами или с любыми другими инфекциями верхних отделов дыхательных путей. Оценивалась антибактериальная активность пеларгонии на бактериях вида Streptococci, Staphylococci, Neisseria, Moraxella catarrhalis u Haemophilus influenza. В результате антибактериальный эффект был обнаружен в отношении микроорганизмов вида Streptococci (Pneumococcus), Staphylococci, Neisseria, Moraxella catarrhalis и Haemophilus influenza. Исследователи пришли к выводу, что препарат может применяться в качестве терапии острых бактериальных инфекций верхних дыхательных путей, однако не стоит отдавать ему предпочтение в случаях, требующих использования традиционных антибактериальных препаратов [15].

Противовирусное действие препарата изучалось в Люксембурге, где была выявлена противовирусная активность экстракта пеларгонии на вирус A H1N1 и - в меньшей степени - A H2N3. Пеларгония ослабляла гемагглютинацию вируса и активность нейраминидазы. В ходе исследования также было отмечено, что экстракт пеларгонии не обладает прямым вируцидным действием и в лабораторных условиях при его применении не наблюдается развития резистентности [16].

Нами накоплен достаточный опыт применения препарата умкалор в лечении инфекционно-воспалительных заболеваний ЛОР-органов, и его эффективность может быть продемонстрирована на примере клинического случая.

Пациентка К., 25 лет, обратилась в ЛОР-клинику Первого МГМУ им. И.М. Сеченова с жалобами на заложенность носа, выделения из носа слизисто-гнойного характера, головную боль и повышение температуры тела до $37,5^{\circ} \mathrm{C}$. Больна в течение трех дней, заболела остро после переохлаждения. Самостоятельно лечилась сосудосуживающими каплями без существенного положительного эффекта. При осмотре: общее состояние удовлетворитель- ное, АД 115 и 75 мм рт. ст., ЧСС 70/мин. Температура тела $37,2{ }^{\circ} \mathrm{C}$. При передней риноскопии: слизистая оболочка полости носа гиперемирована, инфильтрирована. Перегородка носа расположена по средней линии. Носовые ходы сужены за счет инфильтрации слизистой оболочки, в носовых ходах - умеренное количество слизисто-гнойного отделяемого. Нижние носовые раковины увеличены, при анемизации сокращаются достаточно. По данным конусно-лучевой компьютерной томографии околоносовых пазух отмечается снижение пневматизации правой и левой верхнечелюстной пазухи, а также клеток решетчатого лабиринта. Пациентке поставлен диагноз: острый полисинусит, рекомендовано: анемизация полости носа 2 раза в день, интраназально - топические глюкокортикостероиды по 2 дозы в обе половины носа 2 раза в день, ингаляции с $\mathrm{N}$-ацетилцистеином 2 раза в сутки, препарат умкалор 20 капель 3 р/сут. Пациентке проводился ежедневный осмотр с анализом жалоб и динамики клинической картины. На третий день терапии отметила улучшение общего состояния, уменьшение заложенности носа и слизисто-гнойных выделений из полости носа, отсутствие головной боли. При осмотре: общее состояние удовлетворительное, АД 120 и 80 мм рт. ст., ЧСС 66/мин, t = 36,7 ${ }^{\circ} \mathrm{C}$. При передней риноскопии: слизистая оболочка полости носа незначительно гиперемирована, умеренно отечна. Перегородка носа по средней линии. Носовые ходы несколько сужены за счет отека слизистой оболочки, в носовых ходах отделяемого нет. Нижние носовые раковины увеличены, при анемизации сокращаются достаточно. На седьмой день лечения пациентка жалоб не предъявляла, при осмотре данных за острую патологию верхних дыхательных путей обнаружено не было.

Таким образом, фитотерапия имеет несомненную практическую значимость при инфекционно-воспалительных заболеваниях верхних отделов дыхательных путей. Эффективность и безопасность применение препарата умкалор в оториноларингологической практике способствует повышению приверженности пациентов к проводимой терапии.

\section{ЛИТЕРАТУРА}

1 Pelucchi C, Grigoryan L, Galeone C, Esposito S, Huovinen P, Little P, Verheij T, ESCMID Sore Throat Guideline Group, Guideline for the management of acute sore throat. Clinical Microbiology and Infection, 2012, 18(1): 1-28. DOI: 10.1111/j.1469-0691.2012.03766.x

2 Овчинников А.Ю. Острый и хронический фарингит. Вестник оториноларингологии, 1991, 4: 8-10.

3 Bisno AL. Practice guidelines for the diagnosis and management of group A streptococcal pharyngitis. Infectious Diseases in Clinical Practice, 2002, 35(2): 113-25 do 10.1097/00019048-200205000-00013.

4 Рязанцев С.В., Гаращенко Т.А., Карнеева О.В., Поляков Д.П., Свистушкин В.М., Кириченко И.М. Клинические рекомендации. Дифференциальная диагностика и лечение острого тонзиллофарингит. М., 2014. 22 с.

5 Сидоренко С.В., Гучев И.А. Тонзиллофарингит: вопросы диагностики и антибактериальной терапии. Consilium medicum, 2004, 6(4).
6 Teele DN, Klein JO, Rosner B et al. Epidemiology of otitis media during the first seven years of life in children in Greater Boston. Journal of Infectious Diseases, 1989, 160 83-94. doi 10.1093/infdis/160.1.83.

7 Пальчун В.Т. Оториноларингология. Национальное руководство. М.: ГЭОТАРмедиа. 2009: 459-460.

8 Свистушкин В.М., Славский А.Н., Пшонкина Д.М. Бактериофаги в комплексном лечении острого бактериального риносинусита. РМЖ, 2014, 26: 19-25.

9 Анготоева И.Б., Пискунов С.Я., Пискунов Г.З., Козулина М.А. Современная антибиотикотерапия в оториноларингологии. Медицинское Информационное агентство. 2014: 16-19.

10 Барштейн В.Ю. История фитотерапии в памятниках материальной культуры. Античность и раннее средневековье. Медицина. 2011: 13.

11 Мелентьев И. Фитотерапия и фитопрофилактика как средство укрепления здоровья. МОУ «Кадетская школа».
12 Лекарственные травы lektrava.ru. Ссылка активна на 31.01.17.

13 Bereznoy VV, Riley DS, Wassmer Gt, Heger M. Efficacy of extract of Pelargonium sidoides in children with acute non-group A beta-hemolytic Streptococcus tonsillopharyngitis: A randomized, double-blind, placebo-controlled trial. Alternative therapies in health and medicine, 2003 September, 9(5): 68-79.

14 Bachert C, Schapowal A, Funk P, Kieser M. Treatment of acute rhinosinusitis with the preparation from Pelargonium sidoides EPs 7630: A randomized, double-blind, placebocontrolled trial. Rhinology, 2009, 47: 51-58.

15 Uslu H, Yoruk O, Ayyıldız A, Aktan B. Antibacterial spectrum of umckaloabo (Pelargonium sidoides) on upper airway infection agents. European Journal of General Medicine, 2009, 6(4): 245-248.

16 Theisen LL, Muller CP. EPs ${ }^{\circledR} 7630$ (Umckaloabo $\left.{ }^{\circledR}\right)$, an extract from Pelargonium sidoides roots, exerts anti-influenza virus activity in vitro and in vivo. Antiviral Research, 2012, 94(2): 147-156. 